\title{
Lithium - a Loneliness of an Efficacious Unpatented Drug
}

\author{
Stern $L^{1}$, Shvartsur $R^{1,2}$ and Azab $A N^{1,2 *}$ \\ ${ }^{1}$ Department of Nursing, Ben-Gurion University of the \\ Negev, Israel \\ ${ }^{2}$ Department of Clinical Biochemistry and Pharmacology, \\ Ben-Gurion University of the Negev, Israel \\ *Corresponding author: Azab AN, Department \\ of Nursing, Faculty of Health Sciences, Ben-Gurion \\ University of the Negev, P.O.B 653, Beer-Sheva 84105, \\ Israel
}

Received: May 21, 2018; Accepted: June 21, 2018;

Published: June 28, 2018

\begin{abstract}
Lithium is the gold standard drug for maintenance treatment of bipolar disorder. It reduces the recurrence of manic and depressive episodes and decreases the risk of suicide. However, due to its narrow therapeutic index and the fact that its long-term use is associated with several side effects, many clinicians avoid prescribing lithium even to patients who may greatly benefit from its unique therapeutic advantages. In many occasions lithium is sidestepped for fear of side effects, particularly chronic kidney disease. The fact that lithium is an unpatented drug lacking the promotional support of a drug company adds to its relatively lessened glamour.
\end{abstract}

Keywords: Bipolar disorder; Lithium; Nephrotoxicity; Suicide; Therapeutic efficacy

\section{Abbreviations}

BPD: Bipolar Disorder; CKD: Chronic Kidney Disease

\section{Introduction}

Bipolar Disorder (BPD) is a disabling psychiatric disorder upsetting $1-1.5 \%$ of the general population [1]. It is characterized by alternating episodes of mania and depression and other symptoms, which profoundly disturb the mental, social and functional status of the patients and their relatives [2-4]. BPD is associated with increased incidence of comorbidity with a wide range of medical problems $[3,5]$. Moreover, suicidal attempts and suicidal death are major factors that contribute to morbidity and mortality among bipolar patients [6].

The pharmacotherapy of BPD consists of various medications but mainly mood-stabilizers and antipsychotic drugs. Several parameters are usually taken into account when deciding on the choice of administrating particular drugs to individual patients (e.g., severity of symptoms, phase/stage of illness, age, gender, family history, medical condition and comorbidities, past responsiveness to medications, among others) [2,4,7-9]. Mood-stabilizers and antipsychotic drugs are given both during acute episodes of the disease and for preventing recurrence of mood symptoms (maintenance therapy). In some cases, other drugs such as benzodiazepines and antidepressants are added during acute manic and depressive phases of the disease to help stabilize the patient $[2,4,7]$.

Lithium is regarded as the corner-stone of maintenance treatment of BPD [2,4,7]. It has a proven effectiveness against recurrence of manic and depressive episodes [2,4,7-12]. The therapeutic efficacy of lithium seems to be higher when the drug is commenced at early stages of the disease $[8,13,14]$, particularly after first episode of mania [9]. The evidence regarding the ability of lithium to decrease the occurrence of depressive bouts is not indisputable. However, recent data suggest that lithium exerts potent prophylactic antidepressant effects [15]. Consistently, lithium reduces the recurrence of depressive episodes also in patients with unipolar depression [16]. Furthermore, lithium has an established ability to decrease suicidal attempts and suicidal death in patients with unipolar depression [16] and BPD [17-19]. There are other therapeutic benefits that were attributed to lithium [20-25] but some of them are still controversial [26-29].

The precise therapeutic mechanism(s) of action of lithium remain(s) unknown. Since its introduction as a useful mood stabilizer, several hypotheses have been proposed to explain its therapeutic efficacy [30-31]. However, none of these is universally accepted [3439]. A discussion on the mechanism of action of lithium is beyond the scope of this article.

Notwithstanding its established therapeutic efficacy, three factors impede a wider use of lithium: i) it has a plethora of side effects which lead to low adherence and 'discontinuation of the drug in some patients; ii) it has a narrow therapeutic index which imposes close monitoring of its plasma concentrations. Plasma concentrations of lithium that are regarded as effective and relatively safe are between 0.6 to $1.2 \mathrm{mEq} /$ liter $[4,40]$; and, iii) the fact that lithium is an "orphan" drug lacking the promotional support of the pharmaceutical industry. Because lithium is a cheap, naturally occurring chemical, no drug company will invest in its promotion as a useful mood stabilizer. Thus, unfortunately, some clinicians subside or avoid prescribing lithium even in patients who may greatly benefit from its consumption.

Lithium therapy is associated with many side effects $[4,40$ 43]. Possible adverse effects of lithium include gastrointestinal disturbances; neurological problems (e.g., tremor, sedation, weakness, dizziness, memory problems and lack of motivation); cardiovascular alterations (peripheral edema, cardiac arrhythmias and changes in electrocardiogram), skin reactions and aggravation of skin diseases such as acne and psoriasis; endocrine problems (e.g., altered corticosteroids levels and abnormalities in thyroid and parathyroid function); benign leukocytosis; and, most worrying is impairment of kidney function and development of chronic kidney disease (CKD). The severity of side effects may vary between patients, depending on lithium plasma concentration and patients' specific proneness to tolerate the drug. Although the proliferative effect on white blood cells is regarded as an adverse effect of lithium, 
nevertheless, it was suggested as a possible therapeutic strategy for patients with leukopenia $[44,45]$. Another aspect of lithium toxicity is its potential teratogenic effect. The use of lithium during the first trimester of pregnancy has been linked to an increased risk of congenital malformations [40,46], however, subsequent studies questioned this association [41]. Therefore, this concern should not necessarily discourage the use of lithium in pregnant bipolar women, especially those who were already on lithium before conception and are affectively stable (euthymic). This is because lithium has a prominent therapeutic benefit and an established anti-suicidal effect, and also, the fact that other mood stabilizers also have teratogenic effects (particularly valproate, the use of which in pregnant women is associated with an increased incidence of neural tube defects in the newborns $[47,48])$.

As mentioned, the most troublesome side effect of lithium is the development of CKD. In this regard, a large body of data suggests that long-term use of lithium increases the risk of CKD [40,42,43,4952]. However, some studies did not find a causative association between lithium treatment and CKD [41,53]. The response to lithium and severity of its side effects are affected by several factors: patient's characteristics (age, gender, duration of illness, etc.) [4143]; treatment regimen and plasma concentration [41-43], adherence to treatment [2,10]; genetic background [54]; among others. Many studies suggested that administration of low to medium doses of lithium may reduce the incidence of CKD and, thus, that it is important to administer the lowest effective dose of lithium in order to decrease the incidence of side effects and enhance adherence to treatment $[32,43,51,55,56]$. Several preventive measures can be followed to decrease the risk of CKD among bipolar patients who take lithium for long durations $[43,57]$.

The prophylactic effectiveness of lithium against recurrence of mood swings [2,4,7-12] and its anti-suicidal effect [16-19] makes it a preferable choice among many clinicians, patients and their families $[10,12,43,57]$. However, some clinicians avoid using lithium to minimize the risk of nephrotoxicity. It is important to emphasize that other medications that are used for the treatment of BPD also have side effects, some of which are no less harmful than those of lithium $[10,12,58]$. Another important consideration that has to be taken into account is the high cost of newer anti-bipolar drugs such as second generation antipsychotics [59]. Therefore, in order to utilize the favorable effects of lithium, it is important to search for new strategies to reduce its toxicity - CKD in particular - without conceding its therapeutic benefits.

\section{References}

1. Narrow WE, Rae DS, Robins LN, Regier DA. Revised prevalence estimates of mental disorders in the United States: using clinical significance criterion to reconcile 2 surveys' estimates. Arch Gen Psychiatry. 2002; 59: 115-123.

2. Belmaker RH. Bipolar disorder. N Engl J Med. 2004; 351: 476-486.

3. Kupfer DJ. The increasing medical burden of bipolar disorder. JAMA. 2005; 293: $2528-2530$

4. Grande I, Berk M, Birmaher B, Vieta E. Bipolar disorder. Lancet. 2016; 387 1561-1572.

5. Crump C, Sundquist K, Winkleby MA, Sundquist J. Comorbidities and mortality in bipolar disorder: a Swedish national cohort study. JAMA Psychiatry. 2013 70: 931-939.

6. Bostwick JM, Pankratz VS. Affective disorders and suicide risk: a reexamination. Am J Psychiatry. 2000; 157: 1925-1932.

7. Sachs GS, Dupuy JM, Wittmann CW. The pharmacologic treatment of bipolar disorder. J Clin Psychiatry. 2011; 72: 704-715

8. Kessing LV, Vradi E, Andersen PK. Starting lithium prophylaxis early v. late in bipolar disorder. Br J Psychiatry. 2014; 205: 214-220.

9. Berk M, Daglas R, Dandash O, Yücel M, Henry L, Hall am K, et al. Quetiapine v. lithium in the maintenance phase following a first episode of mania: randomised controlled trial. Br J Psychiatry. 2017; 210: 413-421.

10. Calabrese JR, Shelton MD, Rapport DJ, Youngstrom EA, Jackson K, Bilali $\mathrm{S}$, et al. A 20-Month, Double-Blind, Maintenance Trial of Lithium Versus Divalproex in Rapid-Cycling Bipolar Disorder. Am J Psychiatry. 2005; 162: 2152-2161.

11. Geddes JR, Goodwin GM, Rendell J, Azorin JM, Cipriani A, et al. Lithium plus valproate combination therapy versus monotherapy for relapse prevention in bipolar I disorder (BALANCE): a randomised open-label trial. Lancet. 2010; 375: 385-395.

12. Bauer MS, Miller CJ, Li M, Bajor LA, Lee A. A population-based study of the comparative effectiveness of second-generation antipsychotics vs. older antimanic agents in bipolar disorder. Bipolar Disord. 2016; 18: 481-489.

13. Franchini L, Zanardi R, Smeraldi E, Gasperini M. Early onset of lithium prophylaxis as a predictor of good long-term outcome. Eur Arch Psychiatry Clin Neurosci. 1999; 249: 227-230.

14. Hartong EG, Moleman P, Hoogduin CA, Broekman TG, Nolen WA. LitCa Group. Prophylactic efficacy of lithium versus. carbamazepine in treatmentnaive bipolar patients. J Clin Psychiatry. 2003; 64: 144-151.

15. Severus E, Taylor MJ, Sauer C, Pfennig A, Ritter P, Bauer M, et al. Lithium for prevention of mood episodes in bipolar disorders: systematic review and meta-analysis. Int J Bipolar Disord. 2014; 2: 15

16. Abou-Saleh MT, Müller-Oerlinghausen B, Coppen AJ. Lithium in the episode and suicide prophylaxis and in augmenting strategies in patients with unipolar depression. Int J Bipolar Disord. 2017; 5: 11.

17. Goodwin FK, Fireman B, Simon GE, Hunkeler EM, Lee J, Revicki D. Suicide risk in bipolar disorder during treatment with lithium and divalproex. JAMA. 2003; 290: 1467-1473.

18. Baldessarini RJ, Tondo L. Suicidal risks during treatment of bipolar disorde patients with lithium versus anticonvulsants. Pharmacopsychiatry. 2009; 42 : 72-75.

19. Toffol $E$, Hätönen $T$, Tanskanen A, Lönnqvist J, Wahl beck $K$, Joffe G, et al. Lithium is associated with decrease in all-cause and suicide mortality in highrisk bipolar patients: A nationwide registry-based prospective cohort study. J Affect Disord. 2015; 183: 159-165.

20. Leyhe, T, Eschweiler GW, Stransky E, Gasser T, Annas P, Basun H, et al Increase of BDNF serum concentration in lithium treated patients with early Alzheimer's disease. J Alzheimers Dis. 2009; 16: 649-656.

21. Forlenza, OV, Diniz BS, Radanovic M, Santos FS, Talib LL, Gattaz WF Disease-modifying properties of long-term lithium treatment for amnestic mild cognitive impairment: randomised controlled trial. Br J Psychiatry. 2011; 198: 351-356.

22. Fornai $F$, Longone $\mathrm{P}$, Cafaro L, Kastsiuchenka O, Ferrucci M, Manca ML, et al. Lithium delays progression of amyotrophic lateral sclerosis. Proc Natl Acad Sci USA. 2008; 105: 2052-2057.

23. Boll MC, Bayliss L, Vargas-Cañas S, Burgos J, Montes S, PeñalozaSolano G, et al. Clinical and biological changes under treatment with lithium carbonate and valproic acid in sporadic amyotrophic lateral sclerosis. J Neurol Sci. 2014; 340: 103-108.

24. Vita A, De Peri L, Sacchetti E. Lithium in drinking water and suicide prevention: a review of the evidence. Int Clin Psychopharmacol. 2015; 30: 1-5.

25. Ando S, Koike S, Shimodera S, Fujito R, Sawada K, Terao T, et al. Lithium Levels in Tap Water and the Mental Health Problems of Adolescents: An Individual-Level Cross-Sectional Survey. J Clin Psychiatry. 2017; 78: 252256 
26. Macdonald A, Briggs K, Poppe M, Higgins A, Velayudhan L, Lovestone S. A feasibility and tolerability study of lithium in Alzheimer's disease. Int J Geriat Psychiatry. 2008; 23: 704-711.

27. Hampel $H$, Ewers $M$, Bürger $K$, Annas $P$, Mörtberg $A, B$ ogstedt $A$, et al Lithium trial in Alzheimer's disease: a randomized, single-blind, placebocontrolled, multicenter 10-week study. J Clin Psychiatry. 2009; 70: 22-31.

28. Morrison KE, Dhariwal S, Hornabrook R, Savage L, Burn DJ. Lithium in patients with amyotrophic lateral sclerosis (LiCALS): a phase 3 multicentre, randomised, double-blind, placebo-controlled trial. Lancet Neurol. 2013; 12 339-345.

29. Aggarwal SP, Zinman L, Simpson E, McKinley J, Jackson KE, Pinto H, et al. Safety and efficacy of lithium in combination with riluzole for treatment of amyotrophic lateral sclerosis: a randomised, double-blind, placebo-controlled trial. Lancet Neurol. 2010; 9: 481-488.

30. Berridge MJ, Irvine RF. Inositol phosphates and cell signaling. Nature. 1989 341: 197-204.

31. Klein PS, Melton DA. A molecular mechanism for the effect of lithium on development. Proc Natl Acad Sci USA. 1996; 93: 8455-8459.

32. Stambolic V, Ruel L, Woodgett JR. Lithium inhibits glycogen synthase kinase-3 activity and mimics wingless signalling in intact cells. Curr Biol. 1996; 6: 1664-1648.

33. Nassar A, Azab AN. Effects of lithium on inflammation. ACS chemical neuroscience. 2014; 5: 451-458.

34. Azab AN, Agam G, Kaplanski J, Delbar V, Greenberg ML. Inositol depletion: a good or bad outcome of valproate treatment. Future Neurol. 2008; 3: 275286.

35. Agam G, Azab AN. Whether lithium inhibits Glycogen Synthase Kinase (GSK)-3 $\beta$ activity in vivo in humans is still an open question. Bipolar Disord. 2016; 18: 464-467.

36. Azab AN, Vainer E, Agam G, Bersudsky Y. Lymphocyte Phospho-Ser-

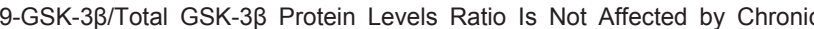
Lithium or Valproate Treatment in Euthymic Patients with Bipolar Disorder. J Clin Psychopharmacol. 2017; 37: 226-230.

37. Wada K, Yamada N, Suzuki H, Lee Y, Kuroda S. Recurrent cases of corticosteroid-induced mood disorder: clinical characteristics and treatment. J Clin Psychiatry. 2000; 61: 261-267.

38. Fields C, Drye L, Vaidya V, Lyketsos C. Celecoxib or naproxen treatmen does not benefit depressive symptoms in persons age 70 and older: Findings from a randomized controlled trial. Am J Geriatr Psychiatry. 2012; 20: 505 513.

39. Raison CL, Rutherford RE, Woolwine BJ, Shuo C, Schettler P, Drake DF, et al. A randomized controlled trial of the tumor necrosis factor antagonis infliximab for treatment-resistant depression: the role of baseline inflammatory biomarkers. JAMA Psychiatry. 2013; 70: 31-41.

40. Baldessarini RJ, Tarazi FI. Pharmacotherapy of psychosis and mania Goodman and Gillman's the Pharmacological Basis of Therapeutics. New York, McGraw Hill. 2006; 461-500.

41. McKnight RF, Adida M, Budge K, Stockton S, Goodwin GM, Geddes JR. Lithium toxicity profile: a systematic review and meta-analysis. Lancet. 2012 379: $721-728$.

42. Shine B, McKnight RF, Leaver L, Geddes JR. Long-term effects of lithium on renal, thyroid, and parathyroid function: a retrospective analysis of laboratory data. Lancet. 2015; 386: 461-468

43. Azab AN, Shnaider A, Osher Y, Wang D, Bersudsky Y, Belmaker RH. Lithium nephrotoxicity. Int J Bipolar Disord. 2015; 3: 28.

44. Lyman GH, Williams CC, Preston D. The use of lithium carbonate to reduce infection and leukopenia during systemic chemotherapy. N Engl J Med. 1980; 302: $257-260$.

45. Kramlinger KG, Post RM. Addition of lithium carbonate to carbamazepine: hematological and thyroid effects. Am J Psychiatry. 1990; 147: 615-620.

46. Cohen LS, Friedman JM, Jefferson JW, Johnson EM, Weiner ML. A reevaluation of risk of in utero exposure to lithium. JAMA. 1994; 12: 146-150.

47. Robert E, Rosa F. Valproate and birth defects. Lancet. 1983; 2: 1142.

48. Verrotti A, Tana M, Pelliccia P, Chiarelli F, Latini G. Recent advances on neural tube defects with special reference to valproic acid. Endocr Metab Immune Disord Drug Targets. 2006; 6: 25-31.

49. Presne C, Fakhouri F, Noël LH, Stengel B, Even C, K reis H, et al. Lithiuminduced nephropathy: Rate of progression and prognostic factors. Kidney Int. 2003; 64: 585-592.

50. Aiff H, Attman PO, Aurell M, Bendz H, Ramsauer B, Schön S, et al. Effects of 10 to 30 years of lithium treatment on kidney function. J Psychopharmacol. 2015; 29: 608-614.

51. Davis JM, Rosenbaum A, Shahinian V, Brosius FC. Prevention of lithiumassociated renal failure: recent evidence. Lancet Psychiatry. 2015; 2: 10451047.

52. Kessing LV, Gerds TA, Feldt-Rasmussen B, Andersen PK, Licht RW. Use of Lithium and Anticonvulsants and the Rate of Chronic Kidney Disease: A Nationwide Population-Based Study. JAMA Psychiatry. 2015; 72: 1182-1191.

53. Clos S, Rauchhaus P, Severn A, Cochrane L, Donnan PT. Long-term effect of lithium maintenance therapy on estimated glomerular filtration rate in patients with affective disorders: a population-based cohort study. Lancet Psychiatry. 2015; 2: 1075-1083.

54. Chen $\mathrm{CH}$, Lee CS, Lee MT, Ouyang WC, Chen CC, Chong MY, et al. Variant GADL1 and response to lithium therapy in bipolar I disorder. N Engl J Med. 2014; 370: 119-128.

55. Aiff H, Attman PO, Aurell M, Bendz H, Schon S, Svedlund J. The impact of modern treatment principles may have eliminated lithium-induced renal failure. J Psychopharmacol. 2014; 28: 151-154

56. Aprahamian I, Santos FS, dos Santos B, Talib L, Diniz BS, Radanovic M, et al. Long-term, low-dose lithium treatment does not impair renal function in the elderly: a 2-year randomized, placebo-controlled trial followed by single-blind extension. J Clin Psychiatry. 2014; 75: 672-678.

57. Shnaider A, Azab AN. Lithium-induced Nephrogenic Diabetes Insipidus - A Case Report and Discussion on the Pathophysiological Mechanism. Int J Nephrol Kidney Failure. 2015; 1.

58. Leucht S, Cipriani A, Spineli L, Mavridis D, Orey D, Richter F, et al. Comparative efficacy and tolerability of 15 antipsychotic drugs in schizophrenia: a multipletreatments meta-analysis. Lancet. 2013; 382: 951-962.

59. Duggan M. Do new prescription drugs pay for themselves? The case of second-generation antipsychotics. J Health Econ. 2005; 24: 1-31.
Austin J Psychiatry Behav Sci - Volume 5 Issue 1 - 2018

ISSN : 2381-9006 | www.austinpublishinggroup.com

Azab et al. () All rights are reserved
Citation: Stern L, Shvartsur R and Azab AN. Lithium - a Loneliness of an Efficacious Unpatented Drug. Austin J sychiatry Behav Sci. 2018; 5(1): 1066 